\section{Effect of Light Intensity and Nutrition Level on Growth and Flowering of Adenium obesum 'Red' and 'Ice Pink'}

\author{
Kaitlyn McBride ${ }^{1}$, Richard J. Henny ${ }^{2,4}$, Jianjun Chen $^{2}$, \\ and Terri A. Mellich ${ }^{3}$ \\ University of Florida, Institute of Food and Agricultural Sciences, Mid- \\ Florida Research and Education Center, 2725 Binion Road, Apopka, FL \\ 32703
}

Additional index words. Apocyanaceae, desert rose, flower number

\begin{abstract}
Adenium obesum (Forssk.), Roem. \& Schult., commonly known as desert rose, is a high-value, container-grown ornamental plant produced worldwide for its bright floral display and striking sculptural caudex. Little scientific-based information exists regarding the effect of light intensity and nutritional levels on Adenium growth and flowering. In this study, $A$. obesum 'Red' and 'Ice Pink' were grown under full sun [with a measured maximum photosynthetically active radiation $(P A R)$ of $1850 \mu \mathrm{mol} \cdot \mathrm{m}^{-2} \cdot \mathrm{s}^{-1}$ ], $30 \%$ shade $\left(1255 \mu \mathrm{mol} \cdot \mathrm{m}^{-2} \cdot \mathrm{s}^{-1}\right)$, or $50 \%$ shade $\left(943 \mu \mathrm{mol} \cdot \mathrm{m}^{-2} \cdot \mathrm{s}^{-1}\right)$ in $1.25-\mathrm{L}$ pots topdressed with controlled-release fertilizer Nutricote ${ }^{\circledR}$ Plus $(18 \mathrm{~N}-2.6 \mathrm{P}-6.6 \mathrm{~K})$ at rates to provide $0.4,0.9$, or $1.4 \mathrm{~g}$ of nitrogen $(\mathrm{N})$ per pot. Canopy height and width, flower number, and visual quality ratings (based on plant size and form, foliage color, and flowering) were highest after 16 weeks of growth for both cultivars when fertilized with $1.4 \mathrm{~g}$ of $\mathrm{N}$ per pot. A $30 \%$ shade level resulted in plants with the highest flower numbers and quality ratings. Plants grown at $50 \%$ shade had the greatest canopy heights and widths, but flower numbers and quality ratings were low. In full sun, plants were smaller overall. In a second experiment, $A$. obesum 'Red' produced the highest shoot dry weight when grown 20 weeks at $30 \%$ or $50 \%$ shade with $1.4 \mathrm{~g}$ of $\mathrm{N}$ per pot. Root formation is an important measure of aesthetic value for this crop. As plants mature, roots enlarge dramatically and are often washed to expose sculptural forms. The highest root dry weights were measured at $1.4 \mathrm{~g}$ of $\mathrm{N}$ under both full sun and $30 \%$ shade.
\end{abstract}

The genus Adenium is a member of the family Apocynaceae and originates from Africa, south of the Sahara from Senegal to Sudan and Kenya, and through Saudi Arabia, Oman, and Yemen (Oyen, 2008; Plaizier, 1980). Commonly known as desert rose, the genus is prized for its attractive floral array atop a swollen, sculptural caudex (Rowley, 1987). As roots mature they swell and enlarge along with the caudex and add an important sculptural element that compliments the flowers; therefore, root formation is an important measure of aesthetic value for this crop (Dimmitt et al., 2009). Adenium plants in a wide range of architectural forms, growth habits, and flower colors are available for sale globally. However, there is no scientific literature regarding Adenium cultural requirements. Production of Adenium species under a minimum $P A R$ of 1000 to $1600 \mu \mathrm{mol} \cdot \mathrm{m}^{-2} \cdot \mathrm{s}^{-1}$ and a temperature range of 30 to $35^{\circ} \mathrm{C}(85$ to $95^{\circ} \mathrm{F}$ ) with high humidity during the growing season has been suggested (Dimmitt, 1998). It also was reported that Adenium responded

Received for publication 21 Nov. 2013. Accepted for publication 27 Jan. 2014.

${ }^{1}$ Graduate Student.

${ }^{2}$ Professor of Environmental Horticulture.

${ }^{3}$ Biological Scientist.

${ }^{4}$ To whom reprint requests should be addressed; e-mail hennyrjz@ufl.edu. and an electrical conductivity of $1.2 \mathrm{dS} \cdot \mathrm{m}^{-1}$. Established landscape plants of Allamanda cathartica 'Hendersonii' were used in an experiment testing four different fertilizers on growth and quality (Broschat et al., 2008). The authors concluded that Allamanda in the landscape may not benefit greatly from increasing fertilization.

Vinca (Catharanthus roseus L.) seedlings benefitted from high concentrations of $\mathrm{N}$ (up to $32 \mathrm{~mm}$ ) in the fertilizer, whereas only low concentrations of phosphorus and potassium (0.25 mM) were needed (van Iersel et al., 1999). Kessler (1998) indicated that pluggrown Vinca seedlings should be fertilized once or twice a week with 50 to $75 \mathrm{mg} \cdot \mathrm{L}^{-1} \mathrm{~N}$. Nitrogen levels could be increased to 100 to $150 \mathrm{mg} \cdot \mathrm{L}^{-1}$ once true leaves develop.

To determine the cultural requirements for producing good-quality desert rose plants in containers, the following study was conducted to determine effects of light and nutritional levels on growth and flowering of Adenium obesum 'Red' and 'Ice Pink', two cultivars that are in commercial production in Florida.

\section{Materials and Methods}

Expt. 1. Established liners from vegetative stem cuttings ( 10 to $15 \mathrm{~cm}$ in height) in 72-cell trays of $A$. obesum 'Red' and 'Ice Pink' were obtained from a commercial propagator (Oglesby Plants International, Inc., Altha, FL). Fifty-four plants of each cultivar were potted into green $1.25-\mathrm{L}(15.2 \mathrm{~cm}$ diameter) azalea pots with Fafard 2 Mix substrate $(65 \%$ peat, $20 \%$ perlite, $15 \%$ vermiculite; Conrad Fafard Inc., Agawam, MA). After potting, all plants were trimmed to 5.0 to $7.5 \mathrm{~cm}$ in height and Nutricote ${ }^{\circledR}$ Plus $(18 \mathrm{~N}-$ $2.6 \mathrm{P}-6.6 \mathrm{~K}$; $140-\mathrm{d}$ formulation) controlledrelease fertilizer (Chisso-Asahi Fertilizer Co., Ltd., Tokyo, Japan) was applied to the substrate surface at $2.5,5.0$, or $7.5 \mathrm{~g}$ per pot (equivalent to $0.4,0.9$, and $1.4 \mathrm{~g} \mathrm{~N}$ per pot). One month after planting, flower buds were removed to promote shoot growth. Fertilizer treatments were reapplied 12 weeks after the initial potting.

Pots were placed onto groundcover beds outdoors under natural daylength and temperature conditions 22 Apr. 2010 at MidFlorida Research and Education Center (MREC), Apopka, FL. Different light intensity treatments were obtained by attaching $1.5-\mathrm{m}$ wide sections of black woven polypropylene shadecloth to a 1.2-m high steel pipe $(1.4 \mathrm{~cm}$ diameter) structure spaced to cover individual growing areas $1.2 \mathrm{~m}$ wide $\times$ $1.5 \mathrm{~m}$ long (Fig. 1). There were 18 individual blocks that were $1.2 \mathrm{~m}$ high, $1.2 \mathrm{~m}$ wide, and $1.5 \mathrm{~m}$ long laid out in north-by-south orientation. Six blocks were covered with woven polypropylene shadecloth at $30 \%$ or $50 \%$ shade rating and six blocks were left unshaded. One plant of each cultivar received each fertilizer treatment under each light level for a total of 54 plants. The use of no shadecloth (i.e., full sun), $30 \%$ or $50 \%$ shadecloth resulted in maximum $P A R$ levels 
of $\approx 1850,1255$, or $943 \mu \mathrm{mol} \cdot \mathrm{m}^{-2} \cdot \mathrm{s}^{-1}$, respectively, in individual growing areas. Light levels were measured biweekly with a LICOR Quantum Radiometer Photometer (Model No. LI-185B; Lincoln, NE). In addition, total solar radiation $\left(\mathrm{W} \cdot \mathrm{m}^{-2}\right)$ was measured throughout each experiment using a LI-COR Model LI-200 pyranometer (LI$\mathrm{COR}^{\circledR}$ Biosciences, Lincoln, NE). Plants were hand-watered as needed for the first 4 weeks after which they received daily irrigation from overhead $20.3-\mathrm{cm}$ spinner sprinklers for 15 min unless it rained. To prevent blowover or knocking over, potted plants in each block were placed in Dillen CTA66 pocket azalea trays $(48 \mathrm{~cm} \times 32 \mathrm{~cm}$ ) (Myers Industries, Middlefield, $\mathrm{OH}$ ).

Final plant canopy height and width, leaf length and width of the first fully expanded leaf on the dominate stem, and visual plant quality were recorded after 16 weeks of growth. The number of open flowers on each plant was recorded weekly. Visual quality rating was based on evaluations and rankings by four observers of overall plant form, foliage quality, and appearance and flower number on the following scale: $1=$ poor; $2=$ fair; 3 = saleable; 4 = good; $5=$ excellent.

Expt. 2. Fifty-four liners of A. obesum 'Red' ( 7 to $9 \mathrm{~cm}$ in height) were potted from 72-cell trays into 1.25 -L (15.2 cm diameter) containers filled with Fafard 2 Mix. To promote lateral branching, plants were trimmed to 5.0 to $7.5 \mathrm{~cm}$ in height. The same fertilizer and application rates as in Expt. 1 were used and pots were placed on groundcover beds outdoors on 25 July 2011 under natural daylength and temperature conditions at MREC, Apopka, FL, using the same growth structures and watering regime as in Expt. 1. Fertilizer treatments were reapplied 12 weeks after initial potting and light treatments consisted of the same $0 \%, 30 \%$, or $50 \%$ shade as in Expt. 1. Twelve weeks after initiation of the experiment, open flowers were first observed and weekly flower counts began and ended 8 weeks later at which time final measurements of canopy height and width and flower counts were made and plants were rated for visual quality using the same scale as in the first experiment. Plants were then cut off at the soil line and the tops bagged in brown paper bags. Roots were removed from

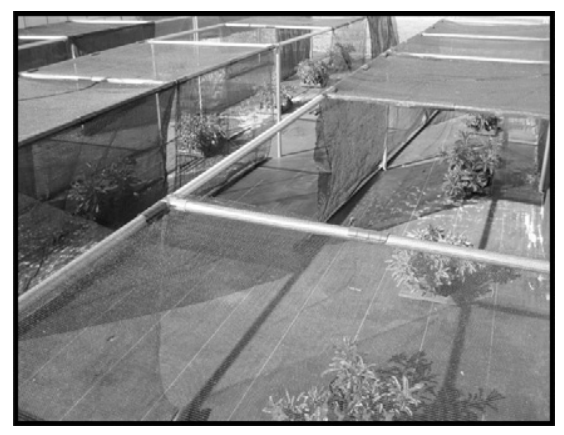

Fig. 1. A view of the shade structures used to grow Adenium obesum 'Red' and 'Ice Pink' at three different light levels. pots and excess soil was washed away; roots were allowed to air-dry for 3 to $4 \mathrm{~h}$ and then were placed in paper bags. The bagged tops and roots were dried in a TD Vac Dryer (Heat Pipe Technology, Gainesville, FL) at $73{ }^{\circ} \mathrm{C}$ $\left(165^{\circ} \mathrm{F}\right)$ for 2 weeks. Dry weights were recorded using a Scout Pro scale (Model No. SPE2001; Ohaus Corporation, Pine Brook, NJ). Data were analyzed using analysis of variance procedures of the SAS program (SAS Institute Inc., Cary, NC).

\section{Results}

Expt. 1. Canopy height and width of $A$. obesum 'Red' increased at higher fertilizer and shade levels, whereas leaf length and width were larger as shade levels increased but did not respond to fertilizer level (Table 1). Adenium 'Red' produced the most flowers when grown at $30 \%$ shade and flower number was greater at the highest fertilizer rate (Fig. 2). Visual plant quality was scored greatest at the 1.4-g N rate and decreased with lower fertilizer levels. Overall, visual plant quality ranked best for plants produced under $30 \%$ shade and $1.4 \mathrm{~g}$ of $\mathrm{N}$.

A. obesum 'Ice Pink' canopy height and width increased as shade and fertilizer levels increased (Table 2). Leaf length and width were greater as shade increased but showed no difference in response to change in fertilizer levels. Flower number declined as shade levels increased, whereas higher fertilizer levels resulted in more flowers regardless of shade level. Similar to A. obesum 'Red', the best rankings for visual quality for 'Ice Pink' plants were produced at $30 \%$ shade at fertilizer rates of 0.9 or $1.4 \mathrm{~g} \mathrm{~N}$ per pot (Table 2).

Expt. 2. After 20 weeks of growth, canopy height and width of $A$. obesum 'Red' plants increased in response to higher fertilizer and shade levels (Table 3). The tallest plants were produced under $50 \%$ shade and $1.4 \mathrm{~g}$ of $\mathrm{N}$, whereas the shortest canopy height occurred at $0.4 \mathrm{~g} \mathrm{~N}$ and $0 \%$ shade (full sun). Similarly, the greatest canopy width was produced with $1.4 \mathrm{~g}$ of $\mathrm{N}$ under $50 \%$ shade, whereas the smallest canopy width was grown at $0.4 \mathrm{~g} \mathrm{~N}$ under $0 \%$ shade (full sun). Like in Expt. 1,

Table 1. Adenium obesum 'Red' growth, average flower number, and visual quality as affected by fertilizer rates (Nutricote Plus 18N-2.6P-6.6K) and light levels after 16 weeks of growth (Apr. to Aug. 2010).

\begin{tabular}{lcccccc}
\hline Shade (\%) & $\begin{array}{c}\text { Canopy } \\
\mathrm{ht}(\mathrm{cm})\end{array}$ & $\begin{array}{c}\text { Canopy } \\
\text { width }(\mathrm{cm})\end{array}$ & $\begin{array}{c}\text { Leaf } \\
\text { length }(\mathrm{cm})\end{array}$ & $\begin{array}{c}\text { Leaf } \\
\text { width }(\mathrm{cm})\end{array}$ & $\begin{array}{c}\text { Total flower } \\
\text { count }\end{array}$ & $\begin{array}{c}\text { Visual } \\
\text { quality }(1-5)^{\mathrm{z}}\end{array}$ \\
\hline 0 & $20.3 \pm 0.7^{\mathrm{y}}$ & $22.8 \pm 1.0$ & $7.0 \pm 0.1$ & $1.6 \pm 0.1$ & $8.9 \pm 1.5$ & $2.9 \pm 0.1$ \\
30 & $22.1 \pm 0.5$ & $27.4 \pm 1.3$ & $7.7 \pm 0.1$ & $1.8 \pm 0.1$ & $12.7 \pm 2.2$ & $3.2 \pm 0.2$ \\
50 & $25.2 \pm 1.1$ & $34.4 \pm 1.3$ & $7.7 \pm 0.1$ & $1.8 \pm 0.1$ & $4.8 \pm 0.7$ & $2.4 \pm 0.1$ \\
LSD $_{0.05}$ & 2.1 & 2.6 & 0.4 & 0.1 & 3.4 & 0.3
\end{tabular}

\begin{tabular}{|c|c|c|c|c|c|c|}
\hline \multicolumn{7}{|l|}{ Fert. (g N/pot) } \\
\hline 2.5 & $20.4 \pm 0.8$ & $23.1 \pm 1.2$ & $7.4 \pm 0.2$ & $1.7 \pm 0.1$ & $2.6 \pm 0.5$ & $2.3 \pm 0.1$ \\
\hline 5.0 & $23.0 \pm 0.9$ & $28.1 \pm 1.2$ & $7.4 \pm 0.1$ & $1.8 \pm 0.1$ & $9.1 \pm 1.1$ & $2.8 \pm 0.1$ \\
\hline 7.5 & $24.1 \pm 0.8$ & $33.0 \pm 1.4$ & $7.6 \pm 0.1$ & $1.7 \pm 0.1$ & $15.3 \pm 2.3$ & $3.3 \pm 0.2$ \\
\hline $\operatorname{LSD}_{0.05}$ & 2.1 & 2.6 & 0.4 & 0.1 & 3.4 & 0.3 \\
\hline Shade ${ }^{x}$ & ** & ** & $* *$ & $* *$ & $* *$ & $* *$ \\
\hline Fertilizer & ** & ** & NS & NS & $* *$ & $* *$ \\
\hline Shade $\times$ fertilizer & NS & NS & NS & NS & ** & $* *$ \\
\hline
\end{tabular}

${ }^{2}$ Visual quality where $1=$ unsalable, $3=$ saleable, $5=$ excellent quality.

${ }^{\mathrm{y}}$ Mean \pm error mean square.

${ }^{\mathrm{NSS}}$, **, nonsignificant or significance at $P \leq 0.01$, respectively.

$\mathrm{LSD}=$ least significant difference.

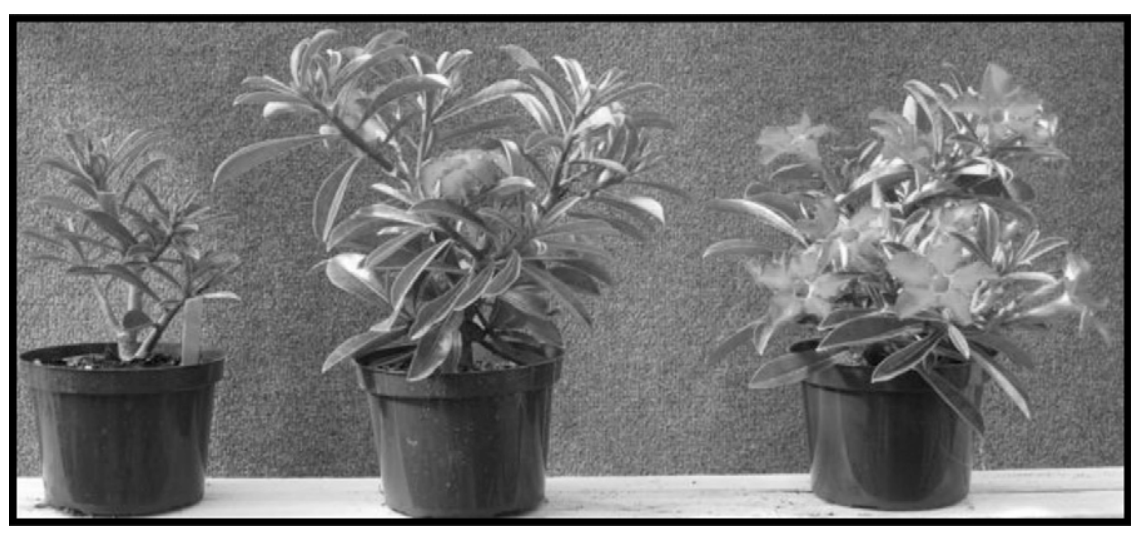

Fig. 2. Adenium obesum 'Red' after 20 weeks of growth in 1.25-L pots with three different fertilizer rates (left to right: $2.5,5.0$, and $7.5 \mathrm{~g})$ Nutricote Plus $(18 \mathrm{~N}-2.6 \mathrm{P}-6.6 \mathrm{~K})$ under $30 \%$ shade from July to Dec. 2011. 
Table 2. Adenium obesum 'Ice Pink' growth, average flower number, and visual quality as affected by light levels and fertilizer rates (Nutricote Plus $18 \mathrm{~N}-2.6 \mathrm{P}-6.6 \mathrm{~K}$ ) after 16 weeks of growth (Apr. to Aug. 2010).

\begin{tabular}{lcccccc}
\hline Shade (\%) & $\begin{array}{c}\text { Canopy } \\
\text { ht }(\mathrm{cm})\end{array}$ & $\begin{array}{c}\text { Canopy } \\
\text { width }(\mathrm{cm})\end{array}$ & $\begin{array}{c}\text { Leaf } \\
\text { length }(\mathrm{cm})\end{array}$ & $\begin{array}{c}\text { Leaf } \\
\text { width }(\mathrm{cm})\end{array}$ & $\begin{array}{c}\text { Total flower } \\
\text { count }\end{array}$ & $\begin{array}{c}\text { Visual } \\
\text { quality }(1-5)^{\mathrm{z}}\end{array}$ \\
\hline 0 & $20.4 \pm 0.8^{\mathrm{y}}$ & $18.0 \pm 0.8$ & $5.2 \pm 0.1$ & $1.8 \pm 0.1$ & $23.1 \pm 2.0$ & $2.7 \pm 0.1$ \\
30 & $23.9 \pm 0.7$ & $21.0 \pm 0.8$ & $5.7 \pm 0.1$ & $2.0 \pm 0.1$ & $24.0 \pm 1.8$ & $3.3 \pm 0.1$ \\
50 & $26.2 \pm 0.8$ & $24.5 \pm 1.2$ & $5.6 \pm 0.1$ & $2.3 \pm 0.1$ & $10.2 \pm 1.0$ & $2.1 \pm 0.1$ \\
LSD $_{0.05}$ & 1.6 & 1.7 & 0.3 & 0.1 & 3.0 & 0.2 \\
Fert. (g N/pot) & & & & & & 2.2 \\
2.5 & $19.2 \pm 0.7$ & $15.6 \pm 0.6$ & $5.5 \pm 0.1$ & $2.1 \pm 0.1$ & $11.8 \mathrm{v} 1.2$ & $2.2 \pm 0.1$ \\
5.0 & $24.2 \pm 0.6$ & $21.4 \pm 0.7$ & $5.4 \pm 0.1$ & $2.0 \pm 0.1$ & $19.1 \pm 1.5$ & $2.8 \pm 0.1$ \\
7.5 & $26.6 \pm 0.7$ & $25.8 \pm 0.9$ & $5.7 \pm 0.1$ & $2.0 \pm 0.1$ & $27.3 \pm 2.1$ & $3.1 \pm 0.2$ \\
LSD 0.05 & 1.6 & 1.7 & 0.3 & 0.1 & 3.0 & 0.2 \\
Shade $^{\mathrm{x}}$ & $*$ & $* *$ & $* *$ & $* *$ & $* *$ & $*$ \\
Fertilizer & $* *$ & $* *$ & NS & NS & $* *$ & $* *$ \\
Shade $\times$ fertilizer & NS & NS & NS & NS & $* *$ & $* *$ \\
\hline
\end{tabular}

${ }^{2}$ Visual quality where $1=$ unsalable, $3=$ saleable, $5=$ excellent quality.

${ }^{\mathrm{y}}$ Mean \pm error mean square.

${ }^{\mathrm{NS}}, * *, *$, nonsignificant or significance at the $P \leq 0.01$ or 0.05 , respectively.

LSD $=$ least significant difference.

Table 3. Effect of three light and fertilizer (Nutricote Plus $18 \mathrm{~N}-2.6 \mathrm{P}-6.6 \mathrm{~K}$ ) levels on canopy height and width, top and root dry weight, flower number, and visual quality of Adenium obesum 'Red' after 20 weeks of growth (July to Dec. 2011).

\begin{tabular}{|c|c|c|c|c|c|c|}
\hline Shade (\%) & $\begin{array}{l}\text { Canopy } \\
\mathrm{ht}(\mathrm{cm})\end{array}$ & $\begin{array}{c}\text { Canopy } \\
\text { width }(\mathrm{cm})\end{array}$ & $\begin{array}{l}\text { Top dry } \\
\text { wt (g) }\end{array}$ & $\begin{array}{l}\text { Root dry } \\
\text { wt (g) }\end{array}$ & $\begin{array}{c}\text { Total flower } \\
\text { count }\end{array}$ & $\begin{array}{c}\text { Visual } \\
\text { quality }(1-5)^{2}\end{array}$ \\
\hline$\overline{0}$ & $18.1 \pm 0.8^{y}$ & $20.5 \pm 1.1$ & $15.0 \pm 1.6$ & $8.5 \pm 0.7$ & $22.7 \pm 4.2$ & $3.1 \pm 0.2$ \\
\hline 30 & $20.8 \pm 0.8$ & $22.3 \pm 1.1$ & $17.2 \pm 1.6$ & $8.0 \pm 0.5$ & $21.2 \pm 3.2$ & $3.6 \pm 0.2$ \\
\hline 50 & $24.3 \pm 0.8$ & $25.3 \pm 1.2$ & $17.9 \pm 1.4$ & $5.6 \pm 0.5$ & $8.3 \pm 2.0$ & $3.1 \pm 0.2$ \\
\hline $\operatorname{LSD}_{0.05}$ & 1.7 & 1.7 & 1.9 & 1.2 & 8.4 & 0.3 \\
\hline \multicolumn{7}{|l|}{ Fertilizer (g N/pot) } \\
\hline 2.5 & $17.8 \pm 0.9$ & $17.7 \pm 0.7$ & $9.4 \pm 0.6$ & $5.5 \pm 0.4$ & $10.6 \pm 3.0$ & $2.4 \pm 0.1$ \\
\hline 5.0 & $22.2 \pm 0.8$ & $23.1 \pm 0.8$ & $16.9 \pm 0.8$ & $7.2 \pm 0.4$ & $15.0 \pm 2.5$ & $3.2 \pm 0.2$ \\
\hline 7.5 & $23.2 \pm 0.9$ & $27.2 \pm 0.8$ & $23.6 \pm 0.8$ & $9.3 \pm 0.7$ & $26.7 \pm 4.0$ & $4.0 \pm 0.1$ \\
\hline $\operatorname{LSD}_{0.05}$ & 1.7 & 1.7 & 1.9 & 1.2 & 8.4 & 0.3 \\
\hline Shade ${ }^{x}$ & $*$ & $* *$ & $*$ & $* *$ & $* *$ & $* *$ \\
\hline Fertilizer & ** & $* *$ & ** & $* *$ & $* *$ & ** \\
\hline Shade $\times$ fertilizer & NS & NS & NS & NS & NS & NS \\
\hline
\end{tabular}

${ }^{2}$ Visual quality rating where $1=$ unsalable, $3=$ saleable, $5=$ excellent quality.

${ }^{\mathrm{y}}$ Mean \pm error mean square.

${ }^{\mathrm{x}} \mathrm{NS}, * *, *$, nonsignificant or significance at the $P \leq 0.01$ or 0.05 , respectively.

$\mathrm{LSD}=$ least significant difference.

flower counts increased with higher fertilizer rates but decreased as shade level increased. The highest average weekly flower counts were produced with $1.4 \mathrm{~g}$ of $\mathrm{N}$ application and at $0 \%$ and $30 \%$ shade, respectively. In contrast, plants grown at the $0.4-\mathrm{g} \mathrm{N}$ rate produced the lowest total flower count at $50 \%$ shade, whereas the next lowest was at $0.9 \mathrm{~g} \mathrm{~N}$ at $50 \%$ shade.

Adenium 'Red' top dry weight exceeded root dry weight in all treatments. Both top and root weight increased at higher fertilizer rates with top dry weight more than doubling as the fertilizer rate increased from 0.4 to $1.4 \mathrm{~g} \mathrm{~N}$ per pot (Table 3 ). Root dry weight was greatest in full sun and at highest fertilizer treatments. This is in contrast to results with Plumeria that showed an increase in root biomass under low nutrient supply (Huante et al., 1995). Adenium 'Red' top dry weight increased as shade increased from $0 \%$ to $50 \%$, whereas root dry weight decreased at higher shade levels. In a study of Betula range (1000 to $\left.1600 \mu \mathrm{mol} \cdot \mathrm{m}^{-2} \cdot \mathrm{s}^{-1}\right)$ that he recommended for Adenium. Our study showed significantly lower flower numbers and lower quality ratings for both $A$. obesum 'Red' and 'Ice Pink' grown at $50 \%$ shade (943 $\left.\mu \mathrm{mol} \cdot \mathrm{m}^{-2} \cdot \mathrm{s}^{-1}\right)$. The average daily solar radiation was 2334 and $1650 \mathrm{~W} \cdot \mathrm{m}^{-2}$ during Expts. 1 and 2, respectively. Although the average total solar radiation was $\approx 30 \%$ less in the later summer/fall test, it did not affect flower number of $A$. obesum 'Red', which produced more flowers in the summer/fall experiment than in the spring/summer experiment.

A. obesum 'Red' and 'Ice Pink' growth was greater as rates of Nutricote ${ }^{\circledR}$ Plus $(18 \mathrm{~N}-$ $2.6 \mathrm{P}-6.6 \mathrm{~K} ; 140-\mathrm{d}$ formulation) increased from 0.4 to $1.4 \mathrm{~g} \mathrm{~N}$ per pot when applied at 12 -week intervals. This agrees with results of a study with Plumeria rubra L, another member of the Apocynaceae family, in which greenhouse-grown plants produced a larger canopy biomass under higher nutrient supply, whereas more biomass was allocated to the roots at a low nutrient supply (Huante et al., 1995). Adenium 'Red' under low nutrient supply relocated more biomass into roots because shoot-to-root ratio of plants grown with $0.4 \mathrm{~g}$ of Nutricote ${ }^{\circledR}$ was 1.7 but increased to 2.5 when grown under $1.4 \mathrm{~g}$ per pot (Table 3 ). A study with Tabernaemontana pachysiphon Staph, another Apocynaceae member, treated with three levels of Osmocote ${ }^{\circledR}$, two water regimes, and two light intensities indicated that increasing nutrient supply and higher light intensity had a positive effect on growth (Hoft et al., 1996).

Results of this study indicate that $A$. obesum 'Red' and 'Ice Pink' should be produced at $30 \%$ shade or a light intensity $\approx 1255 \mu \mathrm{mol} \cdot \mathrm{m}^{-2} \cdot \mathrm{s}^{-1}$ to achieve best quality and highest flower production. If plants are produced in $1.25-\mathrm{L}$ pots, a nutritional regimen that provides 0.9 or $1.4 \mathrm{~g} \mathrm{~N}$ per pot from a slow-release fertilizer source should be provided. Poorest plant quality ratings occurred at the lowest fertilizer level $(0.4 \mathrm{~g} \mathrm{~N}$ per pot $)$ regardless of shade level. Future research is needed to study the effects of higher light levels and fertilization levels on caudex and root development in relation to shoot growth because some markets prefer large caudices in addition to floral displays. The results from the experiments reported here give growers a basis to adapt Adenium for large-scale commercial potted plant crop production.

\section{Literature Cited}

Sheight ratio was $1.7,2.4$, and 2.5 at the 2.5-, 5.0-, or 7.5-g fertilizer rates, respectively.

\section{Discussion}

Adenium obesum can be grown under full sun conditions in central Florida; however, when the plant is commercially produced as an ornamental flowering potted plant crop, this study indicates that best quality plants with the highest flower counts and best quality leaves were produced under $30 \%$ shade (maximum intensity of $\left.\approx 1255 \mu \mathrm{mol} \cdot \mathrm{m}^{-2} \cdot \mathrm{s}^{-1}\right)$. This optimum PAR level supports Dimmitt (1998) and is in the middle of the light intensity 
Ericsson, T. 1995. Growth and shoot:root ratio of seedlings in relation to nutrient availability. Plant Soil 168:205-214.

Hoft, M., R. Verpoorte, and E. Beck. 1996. Growth and alkaloid content in leaves of Tabernaemontana pachysiphon Stapf (Apocynaceae) as influenced by light intensity, water and nutrient supply. Oecologia 107:160-169.

Huante, P., E. Rincon, and I. Acosta. 1995. Nutrient availability and growth rate of 34 woody species from a tropical deciduous forest in Mexico. Funct. Ecol. 9:849-858.
Kessler, J.R. 1998. Greenhouse production of annual Vinca. University, A. A. M. \& University, A. Alabama Cooperative Extension System.

Mart, M. 2012. Strike a pose: Mandevilla vogue. Grower Talks. 76:1-8.

Oyen, L.P.A. 2008. Schmelzer Gh. In: GuribFakim (ed.). Plant resources of tropical Africa. Wageningen, Backhuys.

Plaizier, A.C. 1980. A revision of Adenium Roem. And Schult. and of Diplorhynchus Welw. Ex Fic. and Hiern (Apocynaceae). Mededelingen Landbouwhogeschool. 80:1-40.
Plaza, B.M., S. Jimenez, M. Sebastian, M. Lao, J. Contreras, and M. Segura. 2009. Growth and nutrient evolution of Dipladenia sanderi L. (Apocyanaceae) crop in Mediterranean climate. Acta Hort. 1:571.

Rowley, G.D. 1987. Caudiceform and Pachycaul succulents. Strawberry Press, Mill Valley, CA.

van Iersel, M.W.R.B., P.A. Beverly, J.G. Thomas, and H.A. Mills. 1999. Nitrogen, phosphorus, and potassium effects on pre-and post-transplant growth of salvia and Vinca seedlings. J. Plant Nutr. 22:1403-1413. 